Acta Theriologica 35 (3-4): 191-199, 1990.

PL ISSN 0001-7051

\title{
Response of bank voles to a new source of food and its withdrawal
}

\author{
Joanna BABIŃSKA-WERKA
}

\begin{abstract}
Babińska-Werka J. 1990. Response of bank voles to a new source of food and its withdrawal. Acta theriol. 35: 191-199.

The response of bank voles Clethrionomys glareolus (Schreber, 1780) toward a new source of food and its later withdrawal was studied in a forest environment. Oat grain was used as a kind of food new to rodents in this natural habitat. The process of finding such new supply of food was studied in five groups of stations ( 23 in each) where oat grain was offered in 1 to 5 -day periods. The response of voles toward withdrawal of the food source was studied in four groups of stations (again 23 in each) with variable time passing between food withdrawal and subsequent removal of rodents by snap traps. In the control group of 23 stations no oat grain was offered. The numbers of voles assessed by a regression line for subsequent days of trapping in stations without oat grain and in those where oat 'meals' were offered 1 to 4 days did not differ. It suggested rather rapid location of new food source. In 5 th day there was an increase in numbers of voles coming to the sites with food offered. In the second part of experiment, i.e. this designed to assess the response of voles toward withdrawal of food source, the regression analysis revealed variable numbers of voles: the longer time passing from food withdrawal, the lower number of voles frequenting the site compared with the control sites, i.e. some voles avoided, for couple of days, the sites where new food had been withdrawn.
\end{abstract}

Warsaw Agricultural University, Department of Zoology and Wildlife Management, Rakowiecka 26/30, 02-528 Warsaw, Poland

Key words: Clethrionomys glareolus, food utilisation

\section{Introduction}

Natural food supplies for wild animals fluctuate with time in both quality and quantity. Examples are many: periodical occurrence of certain seeds in annual cycles or irregular mass occurrence of others only once for several years (mast years) (Jensen 1982, 1985, Tchernyshev et al. 1985), and also the gradations of invertebrates - again spaced by years (Koehler 1957, Szujecki 1988). Both seeds and invertebrates are important food items in diet of many rodents.

The new food appearing in the environment may occur on large areas or be limited to certain points. In mast years of oak Quercus robur L. or beech Fagus sylvatica L. in the forest habitats with predomination of these species there is a simultaneous occurrence of large quantities of seeds over large area. On the other hand, sporadic appearance of some plant species, or periodic occurrence of plant seeds are examples of point sources of new foods. The literature of the subject does not provide information how fast the animals are in finding the new sources of food and for how long they remember the emergence of new food at a particular site.

The aim of this project was to assess, on the example of a forest rodent population, the speed of locating newly emerging sources of food and to study the response to its withdrawal. Periodic occurrences of new sources of food were simulated by offering oat 
grain at forest sites. A working hypothesis was: the longer time of oat grain exposure, the greater number of rodents having a chance of finding and using it. As a result, when traps are set at sites of long time of oat grain exposure they should remove more rodents than those put in sites with short-term exposure. Withdrawal of new food should, after some time, be reflected in falling numbers of rodents trapped at the places where food have been previously offered.

\section{Study area, material and methods}

The study was carried out in a 300 -ha forest in the zone adjacent to Suwałki National Park in northeastern Poland $\left(\varphi=54^{\circ} 8^{\prime} \mathrm{N}, \lambda=22^{\circ} 53^{\prime} \mathrm{E}\right)$ close to Turtul locality. It was not too diverse in respect to soil fertility, composition and age of forest stands (Table 1). Past introduction of conifer species caused habitats to shift towards conifer forest type. Undergrowth layer was dominated by Corylus avellana L., Sambucus nigra L., Daphne mezereum L., while the herbaceous layer was not evidently dominated by any particular species with Pteridium aquillinum Kuhn., Fragaria vesca L., Rubus idaeus L., and Aegopodium podagraria $\mathrm{L}$. equally abundant.

Table 1. Characteristics of forest sites where groups of stations were laid out (according to the official maps of the Bureau of Forest Management and Survey). MFD - mixed fresh deciduous forest, FD - fresh deciduous forest.

\begin{tabular}{|c|c|c|c|c|c|c|c|}
\hline \multirow{2}{*}{$\begin{array}{l}\text { Time } \\
\text { (days) }\end{array}$} & \multirow{2}{*}{$\begin{array}{l}\text { Average age } \\
\text { of stand } \\
\text { (years) }\end{array}$} & \multirow{2}{*}{$\begin{array}{l}\text { Potential forest } \\
\text { cover (allowed } \\
\text { by habitat) }\end{array}$} & \multicolumn{5}{|c|}{ Percentage composition of tree species } \\
\hline & & & $\begin{array}{c}\text { Pinus } \\
\text { silvestris }\end{array}$ & $\begin{array}{c}\text { Picea } \\
\text { excelsa }\end{array}$ & $\begin{array}{l}\text { Quercus } \\
\text { robur }\end{array}$ & $\begin{array}{c}\text { Betula } \\
\text { verrucosa }\end{array}$ & $\begin{array}{c}\text { Other } \\
\text { deciduous } \\
\text { species }\end{array}$ \\
\hline \multicolumn{8}{|c|}{$\begin{array}{l}\text { Days of oat } \\
\text { exposure }\end{array}$} \\
\hline 1 & 50 & MFD & 10 & 20 & 50 & & 20 \\
\hline 2 & 50 & MFD & & 20 & 30 & 20 & 20 \\
\hline 3 & 70 & FD & 20 & 70 & & & 10 \\
\hline 4 & 50 & FD & 10 & 60 & 20 & & 10 \\
\hline 5 & 70 & FD & 30 & 30 & 30 & & 10 \\
\hline \multicolumn{8}{|c|}{$\begin{array}{l}\text { Days after oat } \\
\text { withdrawal }\end{array}$} \\
\hline 0 & 70 & FD & 20 & 70 & & & 10 \\
\hline 1 & 80 & MFD & 60 & & & 20 & 20 \\
\hline 3 & 80 & MFD & 60 & 20 & & & 20 \\
\hline 5 & 80 & FD & 50 & & 30 & & 20 \\
\hline Control & 60 & MFD & 30 & 10 & 40 & & 20 \\
\hline
\end{tabular}

The experiments were carried out in July and August 1986. Oat grain was offered in 10 groups of stations (23 in each) arranged in single lines and spaced 100-150 metres. The number of stations was determined by the size of forest and the necessity to space stations with traps. The choice of stations was decided in a way minimalising the variability of vegetation cover both between stations and between their groups (Table 1). In each station, four fundamental features of habitat were assessed namely those regarded by Geuse (1982), Hansson (1978), and Mazurkiewicz $(1984,1986)$ as the most essential for rodents. They were: (1) cover by herbaceous vegetation, (2) diversity of herbaceous vegetation, (3) hidings (fallen trees, heaps of dead branches or stones, etc.), (4) diversity of forest stands. Each feature was rated within four-point 
Table 2. Criteria for habitat evaluation assessment for rodents.

\begin{tabular}{|c|c|c|c|c|}
\hline $\begin{array}{l}\text { Characteristics } \\
\text { of environment } \\
\text { (degree) }\end{array}$ & $\begin{array}{l}\text { Coverage by } \\
\text { herbaceous layer } \\
\text { (per cent } \text { of cover) }\end{array}$ & $\begin{array}{l}\text { Diversity of herbaceous } \\
\text { layer (per cent of species } \\
\text { domination }\end{array}$ & $\begin{array}{c}\text { Hidings } \\
\text { (coverage } \\
\text { of the area in } \mathrm{m}^{2} \text { ) }\end{array}$ & $\begin{array}{l}\text { Diversity of forest } \\
\text { stand }\end{array}$ \\
\hline $\begin{array}{l}0 \\
\text { Very small }\end{array}$ & $<10$ & $\begin{array}{l}\text { Single species domination } \\
\text { over } 80 \%\end{array}$ & $<5$ & $\begin{array}{l}\text { single species, } \\
\text { admixtures }<10 \%\end{array}$ \\
\hline $\begin{array}{l}1 \\
\text { Small }\end{array}$ & $11-50$ & $\begin{array}{l}\text { Single species domination } \\
\text { from } 50 \text { to } 80 \% \text { or two } \\
\text { species co-domination } \\
\text { covering combined } 80 \%\end{array}$ & $5-10$ & $\begin{array}{l}\text { single species, } \\
\text { admixtutes } 10-20 \% \\
\text { or two species, } \\
\text { admixtures }<10 \%\end{array}$ \\
\hline 2 & $51-80$ & $\begin{array}{l}\text { No evidently dominant } \\
\text { species, larger proportion } \\
\text { of fresh coniferous forest } \\
\text { species }\end{array}$ & $11-20$ & $\begin{array}{l}\text { Single species, } \\
\text { admixtures } 20-30 \% \\
\text { or two-species, } \\
\text { admixtures } 10-20 \%\end{array}$ \\
\hline $\begin{array}{l}3 \\
\text { Great }\end{array}$ & $>80$ & $\begin{array}{l}\text { No evidently dominant } \\
\text { species, larger proportion } \\
\text { of mixed coniferous forest } \\
\text { species }\end{array}$ & $>20$ & $\begin{array}{l}\text { Multi-species, } \\
\text { no evident } \\
\text { domination by any } \\
\text { species }\end{array}$ \\
\hline
\end{tabular}

Table 3. Experimental design. 0-oat exposure, "-"-break between oat exposure and trapping, $\mathrm{t}-$ trapping.

\begin{tabular}{|c|c|c|c|c|c|c|c|c|c|c|c|c|c|}
\hline \multirow{2}{*}{$\begin{array}{l}\text { Time } \\
\text { (days) }\end{array}$} & \multicolumn{13}{|c|}{ Days of experiment } \\
\hline & 1 & 2 & 3 & 4 & 5 & 6 & 7 & 8 & 9 & 10 & 11 & 12 & 13 \\
\hline \multicolumn{14}{|c|}{$\begin{array}{l}\text { Days of oat } \\
\text { exposure }\end{array}$} \\
\hline 1 & & & & & & & & 0 & $\mathrm{t}$ & $\mathrm{t}$ & $\mathrm{t}$ & $\mathrm{t}$ & $\mathrm{t}$ \\
\hline 2 & & & & & & & 0 & 0 & $\mathrm{t}$ & $\mathrm{t}$ & $\mathrm{t}$ & $\mathrm{t}$ & $\mathrm{t}$ \\
\hline 3 & & & & & & 0 & 0 & 0 & $\mathrm{t}$ & $\mathrm{t}$ & $t$ & $t$ & $\mathrm{t}$ \\
\hline 4 & & & & & 0 & 0 & 0 & 0 & $\mathrm{t}$ & $\mathrm{t}$ & $\mathrm{t}$ & $\mathrm{t}$ & $\mathrm{t}$ \\
\hline 5 & & & & 0 & 0 & 0 & 0 & 0 & $\mathrm{t}$ & $\mathrm{t}$ & $\mathrm{t}$ & $\mathrm{t}$ & $\mathrm{t}$ \\
\hline \multicolumn{14}{|c|}{$\begin{array}{l}\text { Days after oat } \\
\text { withdrawal }\end{array}$} \\
\hline 0 & & & & & & 0 & 0 & 0 & $\mathrm{t}$ & $\mathrm{t}$ & $\mathrm{t}$ & $\mathrm{t}$ & $\mathrm{t}$ \\
\hline 1 & & & & & 0 & 0 & 0 & - & $\mathrm{t}$ & $\mathrm{t}$ & $\mathrm{t}$ & $\mathrm{t}$ & $\mathrm{t}$ \\
\hline 3 & & & 0 & 0 & 0 & - & - & - & $\mathrm{t}$ & $\mathrm{t}$ & $\mathrm{t}$ & $\mathrm{t}$ & $\mathrm{t}$ \\
\hline 5 & 0 & 0 & 0 & - & - & - & - & - & $\mathrm{t}$ & $t$ & $\mathrm{t}$ & $t$ & $\mathrm{t}$ \\
\hline Control & & & & & & & & & $\mathrm{t}$ & $\mathrm{t}$ & $t$ & $\mathrm{t}$ & $\mathrm{t}$ \\
\hline
\end{tabular}

scale. The assessment according to the above four criteria was made for each station within $25 \mathrm{~m}$ radius (Table 2).

The time of locating a new source of food by rodents was studied in five groups of stations (Table 3). At each station, oat grain was offered in 2 plastic containers of 0.251 each. The durations of exposure were 1,2 , 3,4 , or 5 days in various groups of stations. The oat grain supply was replenished daily. After the time of new food exposure had expired, the rodents were removed during five following days by trapping in five snap traps (with bait of sponge soaked in fried soya-bean oil and flour) set within $1 \mathrm{~m}^{2}$ in each station where oat grain was once offered.

The response of bank voles toward the withdrawal of new food source was studied in four groups of stations. At each station, oat grain was offered during three days in a row (Table 3). In the third day oat was 


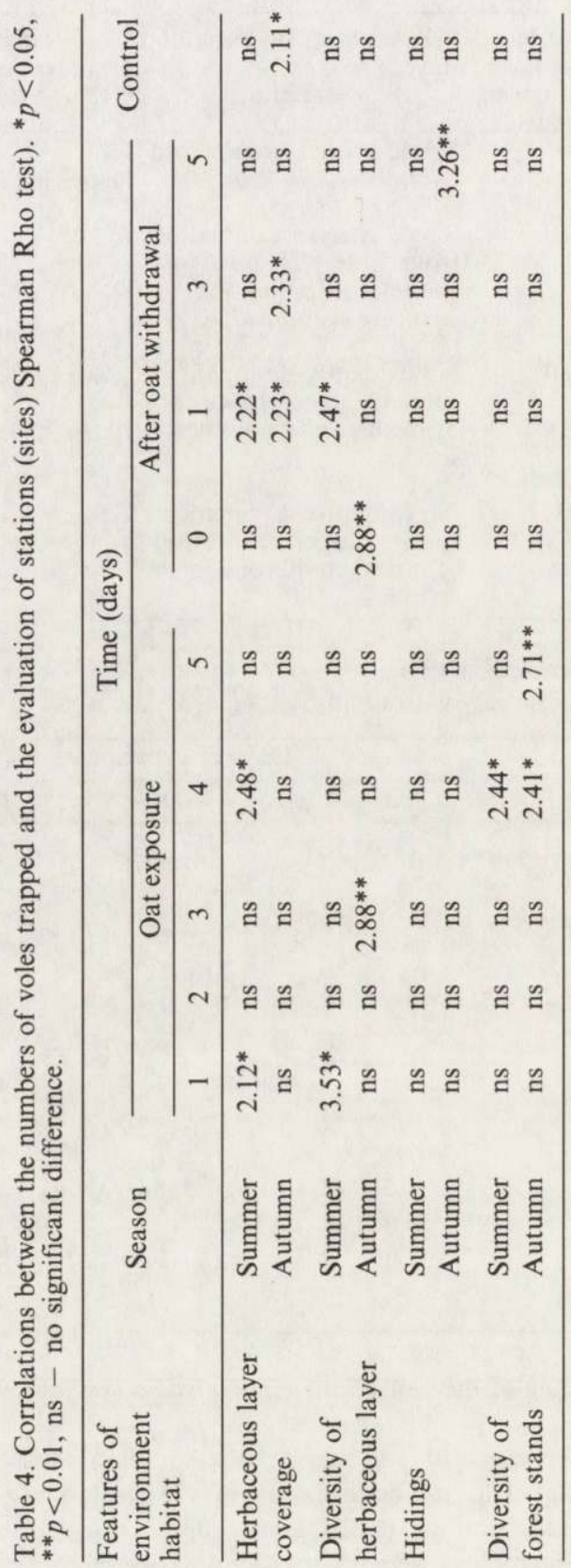


removed to the last grain, and a five-day trapping session followed with variable timing. The trapping started either immediately or was delayed by 1,3 , and 5 days after the food withdrawal.

The control series consisted of another 23 stations where trapping was carried out in the same manner. The trapping session were scheduled to start at the same time at all series.

The rodents collected were identified to species, sexed, weighed and dissected to establish reproductive status of both males and females. Apart from the bank voles Clethrionomys glareolus (Schreber, 1780), there were also yellow-necked field mice Apodemus flavicollis (Melchior, 1834), and striped field mice Apodemus agrarius (Pallas, 1776) collected. In all, 1041 rodents were trapped - 407 in summer, 634 in winter.

\section{Results}

The effect of site on rodent numbers was estimated by evaluating each station where oat grain was offered and rodents collected. It was established that the variation between stations was small enough not to influence the quantitative outcome of trapping. To ensure this uniformity, the scores for four characteristics of the environment were summed up for each site. Next, one-factor analysis of variance was used for to compare combined scores for each station both between groups of stations and between the groups. There were no statistically significant differences in combined scores between particular stations. It meant that all the stations within groups and also groups themselves were similar in respect to its environmental value to rodents.

To check if the rodents had the same chance to be trapped at any station, an Rho Spearman test approximated to Student test was used (Steel and Torrie 1980). This procedure allowed correlating (in both seasons and in all experimental series) the number of rodents trapped at each station with the evaluation scores for each of four features of that particular site. In all, 80 situations were considered (10 groups of stations $\times 4$ evaluated features $\times 2$ seasons). The test revealed the statistically significant differences in only 14 cases (Table 4). They were dispersed randomly in respect to both season of experiment and space (group of stations involved). In the remaining 66 cases the differences were not significant. It allowed assumption that no group of stations was preferred in rodent removal because of special features of the environment.

The rodent fauna in the study area was dominated by the bank vole $(82.9 \%$ in summer, $69.2 \%$ in autumn). The yellow-necked field mouse constituted $15.9 \%$ of summer, and $23.1 \%$ of autumn bag. The occasional occurrence of the striped field mouse was limited to the forest edges. Because of the extent of the bank vole domination in the rodent community it was decided to study the response to both emergence and withdrawal of new food source only in this species.

To determine the actual number of voles coming to stations with oat grain offered, a method establishing simple regression between the number of days of trapping and a sum of voles trapped was used (De Lury 1947, Hayne 1949). For each series of experiment regression equations were calculated (Table 5). The correlation coefficients were high and statistically significant. When $y$ was assumed to be 0 , the equations yielded the number of voles $(x)$ coming to the stations with oat grain (Fig 1.). In summer and autumn, the same number of voles was locating the new food source in 
Table 5. Removal of rodents in the study area.

\begin{tabular}{|c|c|c|c|c|c|}
\hline Season & Time (days) & $\begin{array}{l}\text { Number } \\
\text { of rodents } \\
\text { caught }\end{array}$ & $\begin{array}{l}\text { Regression equatation } \\
\text { for rodent removal }\end{array}$ & $\begin{array}{c}\text { Correlation } \\
\text { coefficient } \\
r\end{array}$ & $\begin{array}{l}\text { Statistical } \\
\text { significance } \\
\text { of } r\end{array}$ \\
\hline & $\begin{array}{l}\text { Days of oat } \\
\text { exposure }\end{array}$ & & & & \\
\hline \multirow[t]{2}{*}{ Summer } & $\begin{array}{l}1 \\
2 \\
3 \\
4 \\
5\end{array}$ & $\begin{array}{l}42 \\
30 \\
35 \\
33 \\
48\end{array}$ & $\begin{array}{l}y=17.52-0.28 x \\
y=17.08-0.28 x \\
y=17.67-0.29 x \\
y=17.75-0.28 x \\
y=18.29-0.26 x\end{array}$ & $\begin{array}{l}0.900 \\
0.880 \\
0.882 \\
0.879 \\
0.881\end{array}$ & $\begin{array}{l}\mathrm{p}<0.05 \\
\mathrm{p}<0.05 \\
\mathrm{p}<0.05 \\
\mathrm{p}<0.05 \\
\mathrm{p}<0.05\end{array}$ \\
\hline & Control & 30 & $y=16.82-0.28 x$ & 0.889 & $\mathrm{p}<0.05$ \\
\hline \multirow[t]{2}{*}{ Autumn } & $\begin{array}{l}1 \\
2 \\
3 \\
4 \\
5\end{array}$ & $\begin{array}{l}53 \\
37 \\
58 \\
51 \\
70\end{array}$ & $\begin{array}{l}y=23.77-0.26 x \\
y=19.40-0.21 x \\
y=21.65-0.21 x \\
y=21.45-0.20 x \\
y=29.72-0.22 x\end{array}$ & $\begin{array}{l}0.962 \\
0.950 \\
0.980 \\
0.961 \\
0.932\end{array}$ & $\begin{array}{l}\mathrm{p}<0.01 \\
\mathrm{p}<0.05 \\
\mathrm{p}<0.01 \\
\mathrm{p}<0.01 \\
\mathrm{p}<0.05\end{array}$ \\
\hline & $\begin{array}{c}\text { Control } \\
\text { Days after oat } \\
\text { withdrawal }\end{array}$ & 46 & $y=18.57-0.19 x$ & 0.900 & $\mathrm{p}<0.05$ \\
\hline Summer & $\begin{array}{l}0 \\
1 \\
3 \\
5\end{array}$ & $\begin{array}{l}35 \\
50 \\
43 \\
31\end{array}$ & $\begin{array}{l}y=17.67-0.29 x \\
y=26.74-0.51 x \\
y=25.60-0.54 x \\
y=19.48-0.57 x\end{array}$ & $\begin{array}{l}0.880 \\
0.991 \\
0.991 \\
0.989\end{array}$ & $\begin{array}{l}p<0.05 \\
p<0.01 \\
p<0.01 \\
p<0.01\end{array}$ \\
\hline Autumn & $\begin{array}{l}0 \\
1 \\
3 \\
5\end{array}$ & $\begin{array}{l}58 \\
33 \\
46 \\
59\end{array}$ & $\begin{array}{l}y=21.65-0.21 x \\
y=18.78-0.19 x \\
y=18.88-0.24 x \\
y=20.00-0.25 x\end{array}$ & $\begin{array}{l}0.881 \\
0.880 \\
0.883 \\
0.879\end{array}$ & $\begin{array}{l}\mathrm{p}<0.05 \\
\mathrm{p}<0.05 \\
\mathrm{p}<0.05 \\
\mathrm{p}<0.05\end{array}$ \\
\hline
\end{tabular}

both control stations and those with oat offered during 1,2,3, and 4 days. That was indicated by the same direction of regression lines (summer, $F=2.61, p>0.05, v_{1}=4$, $v_{2}=17$; autumn, $F=2.48, p>0.05, v_{1}=4, v_{2}=17$ ). In autumn, there was an increasing trend in the estimated number during the initial four days of exposure. It was not earlier than in the fifth day when significantly higher number of voles was locating the new food source (the regression lines were not parallel (summer, $F=5.24, p<0.05, v_{1}=5$, $v_{2}=18$; autumn, $F=4.88, p<0.05, v_{1}=5, v_{2}=18$.

The response of $C$. glareolus toward the withdrawal of the new food source was studied in the same way as in case of locating it, i.e. regression equations were used to assess the number of rodents coming to the station where oat grain was previously offered. The numbers varied among various groups of stations (Fig. 2). In both summer and autumn, there were similar numbers of voles visiting control series stations and coming to the stations where the trapping began after a shortest interval ( $24 \mathrm{hs)}$ following food withdrawal. With longer intervals passing between the food withdrawal and the beginning of trapping (up to 5 days), the number of voles decreased 

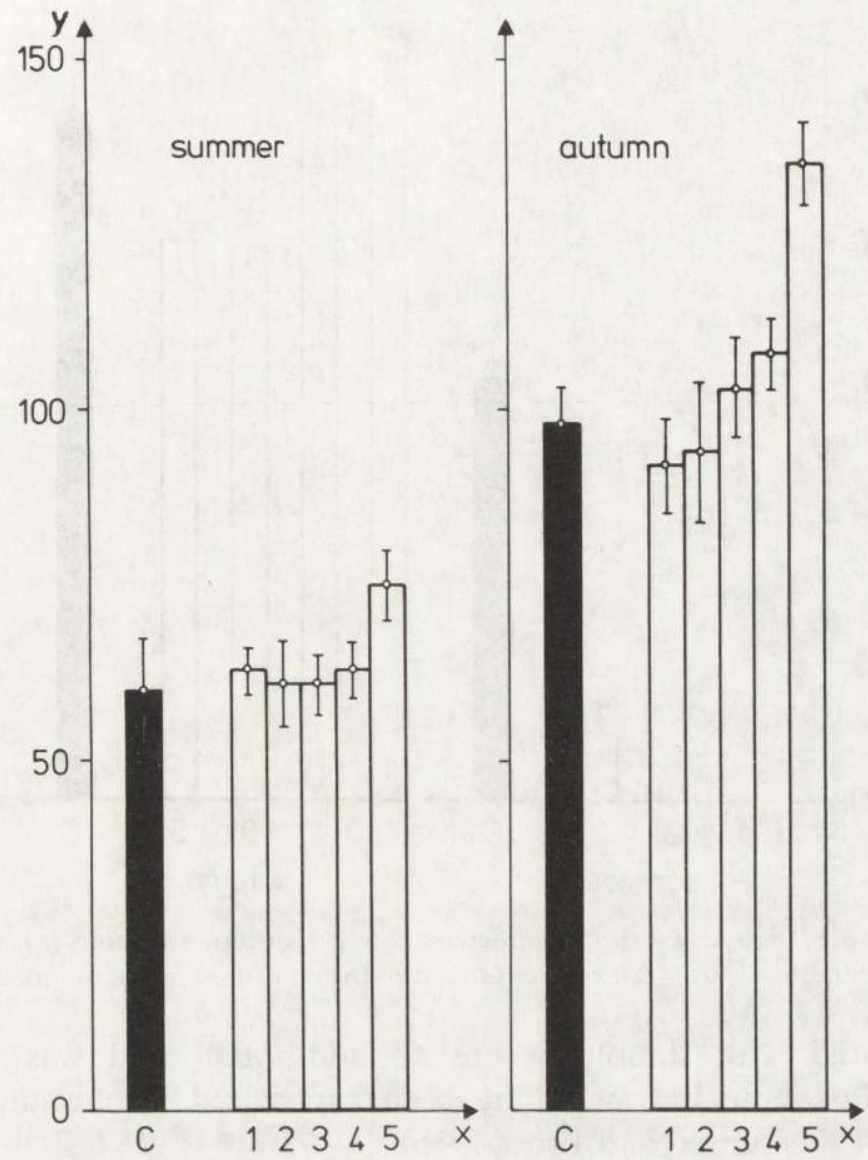

Fig. 1. Number of voles $(y)$ assessed from the regression line in group of stations $(x)$ where oat was exposed for $1,2,3,4$, and 5 days and in the control group of stations.

significantly compared with numbers of animals visiting the control sites (all the regression lines were not parallel: summer, $F=7.24, p<0.05, v_{1}=4, v_{2}=17$; autumn, $\left.F=7.24, p<0.05, v_{1}=4, v_{2}=17\right)$. The drop in number of voles coming to the stations where oat grain had been previously offered was greater in summer than in autumn.

\section{Discussion}

Lacking differences between the numbers of voles coming to the stations where no oat was offered and those visiting the stations where oat grain was exposed for 1,2,3, or 4 days indicated that a bait of soya-bean oil and flour was attractive enough to drawn the voles from the vicinity. The effect of oat grain appeared only in the fifth day of exposure. This fact allowed conclusion that oat grain was also an attractive item, as its longer exposure ( 5 days) could cause the numbers of voles trapped at the stations to 


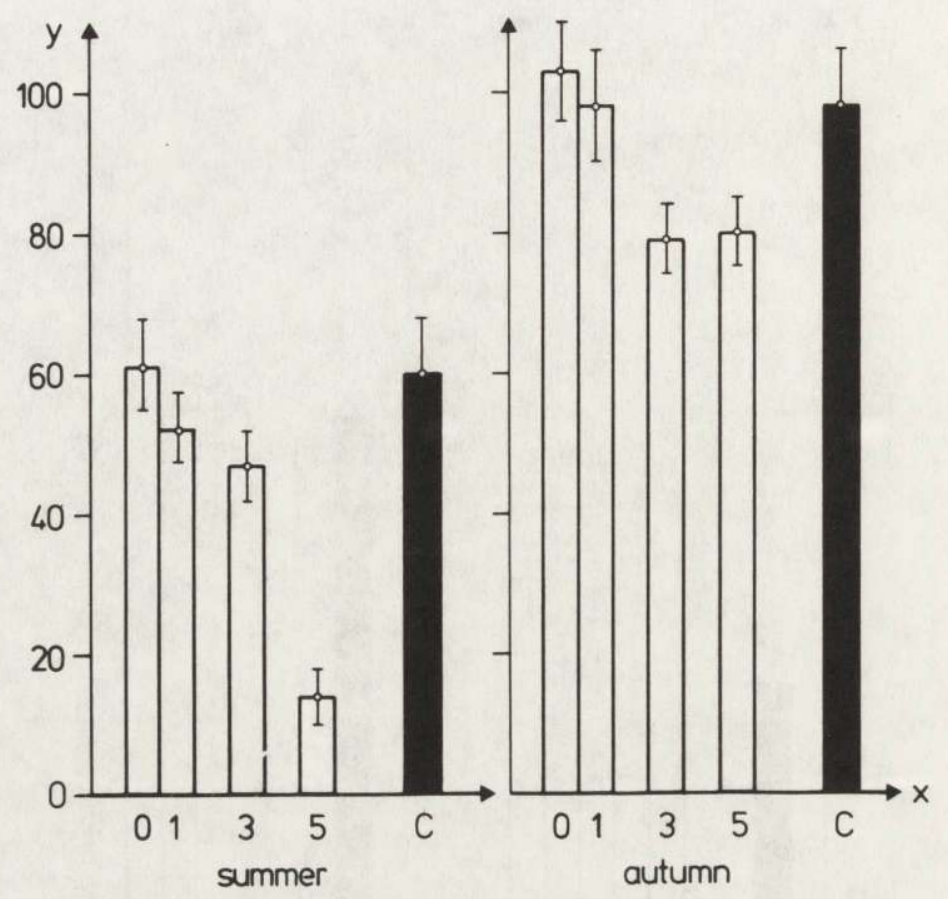

Fig. 2. Number of voles (y) assessed from the regression line in group of stations $(x)$ with variable time elapsing from oat withdrawal $(0,1,3$, and 5 days) and in the control group of stations.

increase compared with stations where no additional food was offered. Such attractiveness of oat grain has, since long, been emphasized by many authors (Drożdż 1966, Hansson 1971, Jensen and Frost 1986).

A surprising result was obtained after introducing a time interval between oat grain exposure and setting traps in a given station. The withdrawal of oat for some time preceding trapping caused the number of voles coming to the station to drop compared with control stations and those where trapping immediately followed the period of grain exposure. These numbers decreased still further when this time interval extended (up to 5 days after the withdrawal). It would suggest that some of the voles having found no oat at certain station changed their area of penetration and hence the oil bait could not attract them back to the places where oat had been previously offered. Perhaps they looked for food in "another area" rather than in places where the food had been exhausted. Time in which the voles returned could not be assessed because it was apparently longer than five days during which the rodents had been removed.

The phenomena follow the same pattern in summer and autumn, although they are more pronounced in autumn. It may be associated with higher population density of rodents in autumn (following seasonal increase in numbers).

The outcome of the experiment indicates that the process of locating new sources of food is very fast. The results cannot warrant speculations if it is a direct effect of 
intensive penetration of the area or if it reflects high olfactory abilities in locating new food. It is possible that both factors participate in the process. When the food disappears at certain site, some voles penetrate "other" areas keeping out of the places where food is no longer available. However, some of the individuals are ready to return immediately and find food at sites where it has previously been present.

Acknowledgements: The author thanks Prof. R. Andrzejewski for his valuable remarks during writing of this paper. The study was carried out under C.P.B.P. 04.10, co-ordinated by the Warsaw Agricultural University.

\section{References}

De Lury D. B. 1947. On the estimation of biological population. Biometrics 3: 145-167.

Drożdż A. 1966. Food habits and food supply of rodents in beech forest. Acta theriol. 11: 363-384.

Geuse P. 1982. Spatial microhabitat of bank vole and wood mice in a forest of central Belgium. Third Intern. Theriol. Congress, Helsinki: 116.

Hansson L. 1971. Small rodents food, feeding and population dynamics: a comparison species in between granivorus and herbivorus in Scandinavia. Oikos 22: 183-198.

Hansson L. 1978. Small mammal abundance in relation to environmental variables in three Swedish forest phases. Stud. Forest. Suec. 147: 5-39.

Hayne D. W. 1949. Two methods for estimating population from trapping records. J. Mammal. 30: $399-411$.

Jensen T. S. 1985. Seed-seed predator interactions of European beech, Fagus silvatica L. and forest rodents Clethrionomys glareolus and Apodemus flavicollis. Oikos 44: 149-156.

Jensen T. S. and Frost N. 1986. Rodents as seed dispersers in a heath-oak wood succession. Oecologia (Berlin) 70: 214-221.

Koehler W. 1957. Osnuja gwiaździsta (Acantholyda nemoralis Thoms.) na tle jej gradacji w borach śląskich. Roczn. Nauk Leśn. 15: 3-93.

Mazurkiewicz M. 1984. Population density of small rodents as affected by chosen elements of tree stand structure. Bull. Acad. Pol. Sci. Cl. II, 32: 209-217.

Mazurkiewicz M. 1986. The influence of undergrowth distribution on utilization of space by bank vole population. Acta theriol. 31: 55-69.

Steel R. G. and Torrie J. H. 1980. Principles and procedures of statistics. McGraw-Hill Book Company, New York: 1-633.

Szujecki A. 1983. Ekologia owadów leśnych. Polish Scientific Publishers, Warszawa: 1-603.

Tchernyshev N. V., Popov I. and Šhvarc E. A. 1985. Dinamika čislennosti, stacialnoe raspredelenie melkih mlekopitajuščih na Valdae i faktory ich opredeljajuščije. [In: Voprosy teriologii. V. E. Sokolov and G. V. Kuznetsov ed.]. Izd. Nauka, Moskva: 100-125.

Received 19 July 1988, accepted 3 July 1990. 